\title{
Inheritance of fire blight resistance in Asian Pyrus species
}

\author{
Kamila L. Bokszczanin ${ }^{1}$, Andrzej A. Przybyla ${ }^{2}$, Malgorzata Schollenberger ${ }^{3}$, Dariusz Gozdowski ${ }^{4}$, \\ Wieslaw Madry ${ }^{4}$, Slawomir Odziemkowski ${ }^{2}$ \\ ${ }^{1}$ Department of Plant Genetics, Breeding, and Biotechnology, Warsaw University of Life Sciences, Warsaw, Poland \\ ${ }^{2}$ Department of Pomology, Warsaw University of Life Sciences, Warsaw, Poland \\ ${ }^{3}$ Department of Plant Pathology, Faculty of Horticulture and Landscape Architecture, Warsaw University of Life Sciences, Warsaw, \\ Poland \\ ${ }^{4}$ Department of Experimental Design and Bioinformatics, Faculty of Agriculture and Biology, Warsaw University of Life Sciences, \\ Warsaw, Poland \\ Email: kamilabokszczanin@,o2.pl, andrzejabp@,o2.pl
}

Received 19 March 2012; revised 28 April 2012; accepted 20 May 2012

\begin{abstract}
Since several Asian pear species are considered to be potential source of fire blight resistance, we crossed 'Doyenné du Comice', the susceptible European cultivar, with four Asian pear species. The aim of the study was to establish the level of resistance of each genotype and the mode of transmission of fire blight resistance to each $F_{1}$ full-sib progeny. The best sources of resistance were $P$. ussuriensis 18 and $P$. ussuriensis var. ovoidea 8 ranked to resistant and highly resistant, respectively. Although pear resistance to fire blight is suggested to be polygenic, distribution of phenotypes in 'Doyenné du Comice' $\times$ P. ussuriensis var. ovoidea 8 hybrid family suggests the possibility of monogenic inheritance with the dominance of resistance derived from $P$. ussuriensis var. ovoidea 8. Polygenic inheritance of pear resistance to fire blight was identified in cross combinations of 'Doyenné du Comice' with $P$. pyrifolia 6 , and contributed by the major gene, with $P$. ussuriensis 18 and $P$. calleryana 12. Transgressive segregation was observed within the progenies of susceptible, moderately susceptible and resistant parents.
\end{abstract}

Keywords: 'Doyenné Du Comice'; Asian Pear Species; Fire Blight Resistance; Pear Interspecific Hybrids;

Polygenic Resistance; Monogenic Resistance; Transgression

\section{INTRODUCTION}

Fire blight is the most devastating disease of pears and apples caused by the bacterium Erwinia amylovora (Burrill) Winslow et al. Symptoms of the disease were noticed as early as 1780 in New York [1]. The bacterial etiology of the disease was recognized in the early 80's of the $19^{\text {th }}$ century by the pioneer of plant pathology Thomas J. Burrill. In 1871 he reported the results con- nected with peach and pear diseases near Cobden, Illinois, where he found first symptoms of fire blight [2]. In 1885 Arthur [3] published his classic paper on the completion of Koch's postulates with the bacterium, thus proving beyond doubt that fire blight was indeed caused by this organism. Erwinia amylovora is considered to be the first proven bacterial plant pathogen $[4,5]$.

The principal and most susceptible hosts are in the subtribe Pyrinae (formerly Pomoideae) of the family Rosaceae. The pathogen is considered to be a quarantine organism and its introduction is prohibited by almost all countries. All plant organs except seeds are considered to be potential source of disseminating this pathogen. All the above and underground parts of hosts can be infected by this pathogen. It can make a considerably reduced yield.

Although fire blight has been known for more than 200 years there is no adequate chemical or other treatment for the elimination of this pathogen from plant material without destroying the plant tissues. The treatment with antibiotic streptomycin is forbidden in the EU.

The most important pear commercial cultivars originnate from $P$. communis and are susceptible to fire blight. The resistance in $P$. communis is relatively rare with only $5 \%-10 \%$ being rated as at least moderately resistant [6-8]. In the European pear cultivars different levels of susceptibility to fire blight are observed. The most resistant main pear cultivars grown in the world are, among others, 'Harrow Sweet' and 'Conference', and the most susceptible 'Doyenné du Comice' [9]. Out of 287 cultivars named prior to 1920 , only $11 \%$ are resistant or highly resistant and out of 113 cultivars released between 1920 and 1978, about one-third were reported to be predominantly resistant [10]. The US National Clonal Germplasm Repository (NCGR) Pyrus collection possesses more than 160 pear clones identified as being highly to moderately resistant to fire blight. Fire blight resistant accessions include 22 Asian cultivars, 80 European and hybrid culti- 
vars, 2 ornamental cultivars and 61 rootstock and species selections [11].

Breeding for pear resistance to fire blight began in the nineteenth century after the introduction of Japanese sand pear (P. pyrifolia) to the eastern part of the United States [12]. The first fire blight resistant pear cultivar was 'Patten' released from Iowa Experimental Station after the introduction of Chinese pear P. ussuriensis [13]. Old dessert cultivars most consistently rated as resistant are 'Alexander Lucas', 'Tyson', 'Seckel', and 'Maxine' [14]. Resistant cultivars developed by later breeding are 'Harrow Delight', 'Harrow Sweet', 'Honeysweet' and 'Magness'. 'Gourmet' and 'Honeysweet' are fire blight resistant interspecific hybrids of $P$. communis $\times P$. ussuriensis parentage developed for the northern plains of North America where cold hardiness is essential. All other European, circum-Mediterranean, and mid-Asian species are generally susceptible [14]. A high level of resistance occurs in higher frequency among the East Asian pear species. As the sources of resistance van der Zwet and Keil [15] ranked in descending order based on their degree of fire blight resistance: $P$. ussuriensis, P. calleryana, $P$. betulaefolia, P. pyrifolia, and P. communis. Hartman [4] listed resistant individuals within $P$. calleryana, $P$. betulaefolia, P. phaeocarpa, P. faurieri, and P. variolosa. Since the pathogen is not known to occur in Asia, it is proposed that fire blight resistance in Asian species evolved independently of the fire blight pathogen.

The strategy of reducing the host susceptibility to fire blight infection is especially valuable for Integrated Fruit Production (IFP). Prior to 2002, no information on molecular genetics of pear existed. Since then a few genetic maps based on molecular markers have been described [16-18] as well as the first report on quantitative trait loci (QTLs) linked to fire blight resistance genes in LG 2, 4, and 9 of resistant cv 'Harrow Sweet' was made by Dondini et al. [19]. For the first time a putative QTL for fire blight resistance in $P$. ussuriensis 18 linkage group 11 and putative QTL in linkage group 4 of susceptible 'Doyenné du Comice' were reported [20]. Genetic resistances are more often identified in wild species, botanical varieties or obsolete cultivars with mediocre appearance and quality. The use of wild species is very problematic because of its extremely bad fruit quality and small fruit size. Since biotechnology tools can help to solve the transmission of resistance genes into established cultivars, a pear breeding program with Asian pear species as the sources of fire blight resistance was initiated in 2003 at Warsaw University of Life Sciences, Department of Pomology.

The objective of the present study was to determine the levels of fire blight resistance in Asian pear species, European pear cultivar 'Doyenné du Comice' and the hybrid families as well as to evaluate the transmission of resistance to $F_{1}$ full-sib progeny.

\section{MATERIALS AND METHODS}

\subsection{Plant Materials and Crosses}

In order to obtain $F_{1}$ full-sib progeny, interspecific crosses were performed using the cultivar 'Doyenné du Comice' originated from $P$. communis, susceptible to fire blightfemale component and the following accessions of Asian pear species: $P$. calleryana $12, P$. pyrifolia $6, P$. pyrifolia 19, P. ussuriensis 18 , and P. ussuriensis var. ovoidea 8 pollen donors. Hand-pollination method was employed with flower emasculation at balloon stage by tearing away the calyx cup pinching it with the fingernails. Crosses were carried out in May 2003-2007 in the Wilanow orchard of the Department of Pomology, Warsaw University of Life Sciences. To enlarge progeny, crosses of 'Doyenné du Comice' with Asian pear species were repeated for few consecutive years, i.e. for P. calleryana 12 in 2004 and 2005, for P. pyrifolia 6 in 2003-2006, for P. pyrifolia 19 in 2004 and 2005, for $P$. ussuriensis 18 in 2003-2007, and for P. ussuriensis var. ovoidea 8 in 20032006. Seedlings obtained in the current year served for one-year observations.

\subsection{Artificial Shoot Inoculation}

The greenhouse-resistance assessments of the seedlings and parental forms were performed in the summer of 2004-2009 at Warsaw University of Life Sciences, Department of Pomology, in cooperation with the Department of Plant Pathology.

Parental forms were grafted in ten replicates on the potted seedlings of $P$. communis L. subsp. caucasica (Fed.) Browicz. At the time of vegetation from each scion two shoots were developed. Seedlings were not grafted. At the turn of June and July, according to method used by Bell et al. [21], two youngest leaves of $50 \mathrm{~cm}$ tall shoots were dissected with scissors dipped in the inoculum of $E$. amylovora (Burrill) Winslow et al., highly virulent strain $691\left(10^{8} \mathrm{cfu} \cdot \mathrm{ml}^{-1}\right)$, isolated from 'Šampion' apple $\mathrm{cv}$ in 1998 at Research Institute of Pomology and Floriculture, Skierniewice, Poland. In order to provide high humidity conditions after inoculation the plants were covered with plastic bags for 24 hours. During 4 weeks of evaluation the following mean values were maintained: $27^{\circ} \mathrm{C}$ (day), $21^{\circ} \mathrm{C}$ (night) and $55 \%$ air humidity.

Starting one week after inoculation and continuing for four consecutive weeks the plants were scored for the progression of the disease. The fire blight lesion length and total length of the current season's growth of the inoculated shoots were measured. The severity of infection was expressed as the length of the fire blight lesion 
(necrosis) as a percentage of the overall shoot length after 1, 2, 3 and 4 weeks after inoculation. In the case of grafted plants the measurements were averaged over all replicates. The level of resistance of parental forms was established by employing Gardner scale [22]: $0 \%-10 \%$ highly resistant, 10\% - 30\% resistant, 30\% - 50\% moderately susceptible, 50\% - 90\% susceptible, and 90\% $100 \%$ highly susceptible. Each next class starts above the upper limit of the previous one. In order to obtain accurate results on the transmission of the studied trait, the distribution of individuals in each $F_{1}$ full-sib progeny was investigated in ten classes of resistance: $0 \%-10 \%$, $10 \%$ - 20\%, 20\% - 30\%, 30\% - 40\%, 40\% - 50\%, 50\% $60 \%, 60 \%-70 \%, 70 \%-80 \%, 80 \%-90 \%, 90 \%-100 \%$. These classes correspond to the classes of Gardner, i.e. $0 \%-10 \%$ highly resistant, $10 \%-30 \%$ resistant etc.

\subsection{Statistical Analysis}

The data for the fire blight infection recorded on each offspring resulted from interspecific crosses were subjected to statistical analysis. Descriptive statistics were used separately for each hybrid family. Mean, median, minimum and maximum value of necrosis, lower and upper quartile, standard deviation, coefficient of variation, and skewness were computed.

Pearson's chi-square test was chosen to check if resistance distribution in each seedling progeny depends on parental combination.

The Kolmogorov-Smirnov one-sample test was used to test the hypothesis about the normal distribution of phenotypes in each hybrid family.

The shape of the observed non-normal, continuous distribution of phenotypes in 'Doyenné du Comice' $\times P$. ussuriensis var. ovoidea 8 progeny was analyzed with Gaussian mixture simulation.

The data for the fire blight severity recorded on 5 progenies and 6 parents for 4 measurement times were analyzed using two stage cluster analysis. At the first stage the variables were values for individual plants for each cross separately (from 12 to 155 depending on cross). Groups of plants with similar pattern of fire blight infection were distinguished within each hybrid family. At the second stage mean values for distinguished groups and mean values for parents were used for cluster analysis for all five crosses together. Classification of genotypes and groups of genotypes into homogenous groups was carried out using Ward's method of cluster analysis. The squared Euclidean distance was used as the dissimilarity measure between genotypes. The analyses were conducted using Statistica 7.1 package, StatSoft 2005.

\section{RESULTS}

Both the number of individuals obtained from each cross of 'Doyenné du Comice' with Asian pear species, and the distribution of these individuals in classes of resistance in each $\mathrm{F}_{1}$ progeny are given in Table $\mathbf{1}$.

It was found, that the levels of disease severity depended very much on cross combination $(p<0.0001)$. The probability of the occurrence of observed numbers of seedlings in classes of resistance at the assumption of independence between the infection level and cross combination would be much less than $0.001 \%$.

Among the tested genotypes the highest level of resistance showed botanical ussurian pear variety- $P$. ussuriensis var. ovoidea 8 with a mean lesion length of $2.34 \%$, which corresponds to a highly resistant class. Both $P$. ussuriensis 18 and $P$. pyrifolia 6 were classified as resistant and ranked in the $2^{\text {nd }}$ class (with the lesion length of $15.87 \%$ and $24.10 \%$, respectively). In the $3^{\text {rd }}$ class (moderately susceptible) the following were ranked: $P$. calleryana 12, P. pyrifolia 19, and 'Doyenné du Comice' with the severity of infection expressed by $31.67 \%, 43.43 \%$ and $49.41 \%$ respectively (Table 2 ).

Different levels of resistance were observed between genotypes of the same species like between $P$. pyrifolia 6 and $P$. pyrifolia 19 as well as between $P$. ussuriensis 18 and $P$. ussuriensis var. ovoidea 8 (Table 2).

To characterize the distribution of phenotypes in different interspecific crosses the mean, median, minimum and maximum value of necrosis, lower and upper quartile, standard deviation, coefficient of variation, and skewness were taken into account (Table 3). In the interspecific cross 'Doyenné du Comice' $\times$ P. pyrifolia 19 the highest mean susceptibility value and the lowest coefficient of variation were observed (Table 3, Figure 1). Half of the progeny was ranked to susceptible and highly susceptible

Table 1. Distribution of individuals in each $F_{1}$ progeny according to percentage of lesion length.

\begin{tabular}{|c|c|c|c|c|c|c|c|c|c|c|c|}
\hline \multirow{3}{*}{ 'Doyenné du Comice'× } & \multicolumn{10}{|c|}{$\%$ of lesion length (necrosis) } & \multirow{3}{*}{ No. of individuals } \\
\hline & $0-10$ & $10-20$ & $20-30$ & $30-40$ & $40-50$ & $50-60$ & $60-70$ & $70-80$ & $80-90$ & $90-100$ & \\
\hline & \multicolumn{10}{|c|}{ No. of individuals in classes of resistance } & \\
\hline P. calleryana 12 & 6 & 12 & 16 & 2 & 1 & 0 & 1 & 0 & 0 & 0 & 38 \\
\hline P. pyrifolia 6 & 4 & 3 & 10 & 15 & 18 & 13 & 8 & 8 & 2 & 8 & 89 \\
\hline P. pyrifolia 19 & 0 & 1 & 1 & 0 & 3 & 1 & 0 & 2 & 2 & 2 & 12 \\
\hline P. ussuriensis 18 & 12 & 43 & 47 & 23 & 11 & 3 & 10 & 2 & 1 & 3 & 155 \\
\hline P. ussuriensis var. ovoidea 8 & 21 & 19 & 9 & 12 & 6 & 5 & 4 & 2 & 0 & 7 & 85 \\
\hline
\end{tabular}

$0 \%$ - 10\% highly resistant, $10 \%$ - 30\% resistant, 30\% - 50\% moderately susceptible, $50 \%$ - $90 \%$ susceptible, $90 \%$ - $100 \%$ highly susceptible. 
Table 2. Level of resistance to fire blight of 'Doyenné du Comice' and Asian pear species (average from 2008-2009).

\begin{tabular}{ccc}
\hline Genotype & Mean fire blight necrosis (\%) & Class of resistance $^{*}$ \\
\hline 'Doyenné du Comice' & 49.41 & 3 \\
P. calleryana 12 & 31.67 & 3 \\
P. pyrifolia 6 & 24.10 & 2 \\
P. pyrifolia 19 & 43.43 & 3 \\
P. ussuriensis 18 & 15.87 & 2 \\
P. ussuriensis var. ovoidea 8 & 2.34 & 1 \\
\hline
\end{tabular}

${ }^{*} 1$ - highly resistant $(0 \%$ - 10\%), 2-resistant $(10 \%$ - 30\%), 3-moderately susceptible $(30 \%$ - 50\%), 4-susceptible $(50 \%$ - $90 \%), 5$-highly susceptible $(90 \%$ $-100 \%)$.

Table 3. Mean, median, minimum and maximum value of necrosis, lower and upper quartile, standard deviation, coefficient of variation, and skewness in hybrid families.

\begin{tabular}{cccccccccc}
\hline 'Doyenné du Comice'× & Mean & Median & Min. & Max. & Lower Quartile & Upper Quartile & Std.Dev. & Coef.Var. & Skewness \\
\hline P. calleryana 12 & 21.05 & 20.98 & 6.32 & 63.35 & 14.18 & 27.03 & 11.00 & 52.26 & 1.58 \\
P. pyrifolia 6 & 50.50 & 46.03 & 6.71 & 100.00 & 34.48 & 63.83 & 23.91 & 47.35 & 0.47 \\
P. pyrifolia 19 & 63.75 & 63.23 & 19.23 & 100.00 & 47.95 & 86.54 & 26.91 & 42.22 & -0.16 \\
P. ussuriensis 18 & 24.92 & 21.97 & 0.00 & 100.00 & 14.52 & 29.86 & 16.57 & 66.49 & 2.39 \\
P. ussuriensis var. ovoidea 8 & 28.46 & 21.77 & 0.00 & 100.00 & 9.54 & 43.16 & 24.35 & 85.55 & 1.08 \\
\hline
\end{tabular}
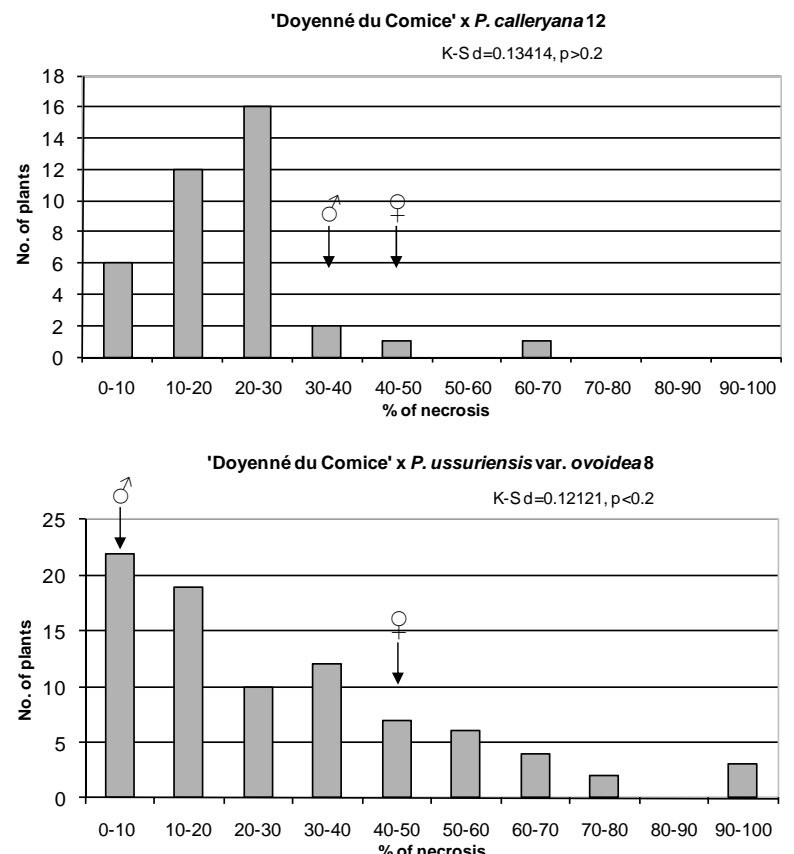

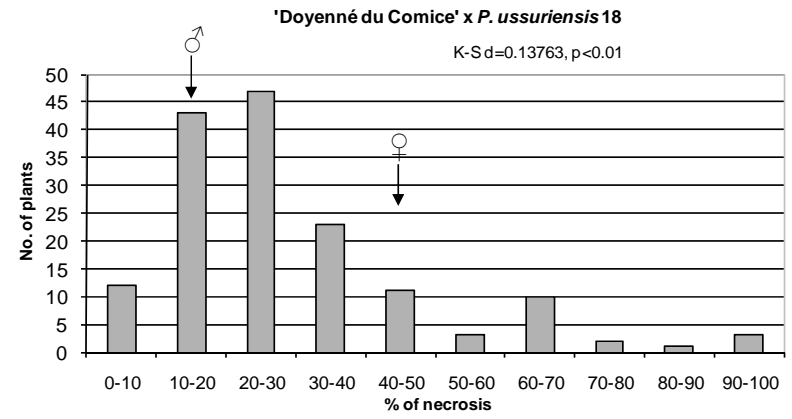

'Doyenné du Comice' x P. pyrifolia 6

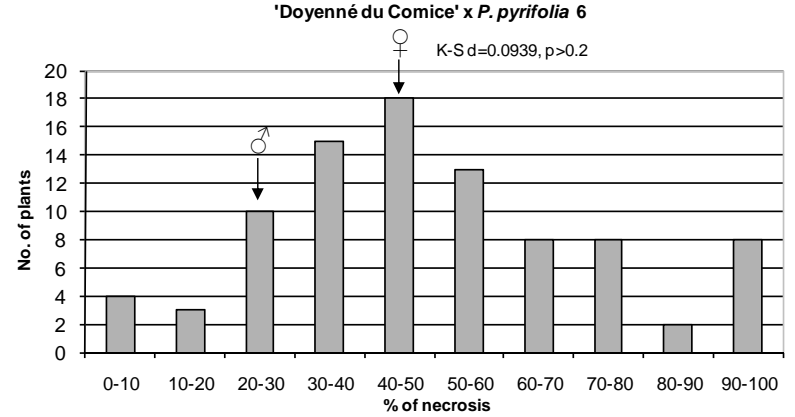

'Doyenné du Comice' x P. pyrifolia 19

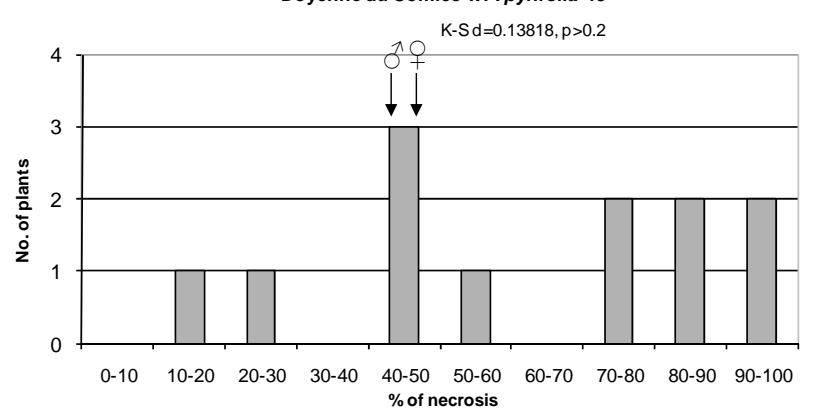

Figure 1. Distribution of $\mathrm{F}_{1}$ full-sib progeny in classes of fire blight (Erwinia amylovora) resistance. Arrows indicate range of parental fire blight necrosis $(+$, female; $\hat{\partial}$, male). Results of the Kolmogorov-Smirnov one-sample test for normality are given under the title of each histogram. 
class with the lesion length not less than $63 \%$. In a quarter of the progeny there was necrosis equal to or greater than 86.5\% (Table 3). Seedlings distribution appeared to be not continuous (gradually presented), since there were no genotypes with $30 \%-40 \%$ and $60 \%-70 \%$ of the severity of fire blight infection (Figure 1). Resistant seedlings were not observed due to either a low number of seedlings or lack of valuable alleles in the male parent.

On the contrary, in 'Doyenné du Comice' $\times P$. calleryana 12 population susceptible seedlings were not observed. The lowest mean value of both lesion length and standard deviation were noted. In three quarter of the progeny necrosis did not exceed $27 \%$ and in half-21\% (Table 3). The most numerous class was resistant with the lesion length ranged from $10 \%-30 \%$ (Figure 1). It is a result of either a low number of seedlings or the presence of valuable resistance alleles in P. calleryana 12 .

The lowest skewness equal to 0.47 and phenotypic mean value of 50.50 were attributed to 'Doyenné du Comice' $\times P$. pyrifolia 6 cross combination implicating the symmetric distribution of resistance/susceptibility trait. It is also expressed by the median value closed to the mean since necrosis evaluated in one half of the progeny was reported to be equal to or greater than $46 \%$ (Table 3). In comparison to the remaining hybrid families, there occurred the greatest number of seedlings classified as highly susceptible with $100 \%$ of the disease severity. The average difference between plant necrosis and the mean amounted to 24 (Table 3). Phenotypic values were relatively evenly distributed on both sides of the mean, resembling bell-shaped distribution characteristic for polygenic traits. The hypothesis that the respective distribution is normal was confirmed by the KolmogorovSmirnov one-sample test (Figure 1).

Only in the interspecific crosses of 'Doyenné du Comice' $\times P$. ussuriensis 18 and 'Doyenné du Comice' $\times$ $P$. ussuriensis var. ovoidea 8 highly resistant seedlings with no symptoms were observed -12 and 21 individuals respectively. Moreover half of the progeny appeared to be infected with necrosis equal to or less than $22 \%$ (Table 3).

In the case of 'Doyenné du Comice' $\times P$. ussuriensis 18 the greatest positive skew of the distribution was observed with the mass of the distribution concentrated on the left of the figure. Predominant number of individuals was ranked to the resistant class with the lesion length ranging from $21 \%$ - 30\% (Figure 1). In a quarter of the progeny necrosis did not exceed $14.5 \%$ (Table 3). This interspecific cross transmitted resistance to $65 \%$ of its offspring ranked to two resistant classes ranged from $0 \%-30 \%$ of fire blight severity.

'Doyenné du Comice' $\times P$. ussuriensis var. ovoidea 8 is the sole interspecific cross where the most numerous $1^{\text {st }}$ class of resistance was noted (Figure 1). A quarter of the progeny was ranked as highly resistant with necrosis equal to or less than $9.5 \%$. Individuals determined to be moderately susceptible to highly resistant constituted three quarter of the progeny with the lesion length less than $43 \%$. It was found that the coefficient of variation was the highest when compared to the rest of families with a standard deviation only about $15 \%$ below the mean (Table 3). Non-normal, but still a continuous distribution of phenotypes was observed (Figure 1). 'Doyenné du Comice' $\times$ P. ussuriensis var. ovoidea 8 cross resulted in the transmission of the highest level of resistance to their offspring, with $58 \%$ of the offspring in the $1^{\text {st }}$ highly resistant and $2^{\text {nd }}$ resistant class, presumably as an outcome of monogenic inheritance. Simulation analysis revealed Gaussian mixture distribution of phenotypes (Figure 2), observed also by Layne et al. [23] and described and illustrated by Allard [24] as attributed to monogenic inheritance with dominance for resistance and 50 percent heritability.

In all studied hybrid families, transgressive individuals more resistant or more susceptible than their respective parents were observed (Figure 1).

Figure 3 presents major trend patterns of the fire blight severity across 4 time measurements for hybrid family groups obtained by cluster analysis (three groups within each family) and mean values of parent necrosis $(\%)$. At the second stage of cluster analysis four clusters of genotypes (groups of crosses and parents) were distinguished (Figure 4). The most resistant was cluster 1, where there was only one parent i.e. P. ussuriensis var. ovoidea 8 . The mean percentage of necrosis in fourth measurement for $P$. ussuriensis var. ovoidea 8 was equal to $2.3 \%$ (Table 4). Groups of the following crosses: 'Doyenné du Comice' $\times$ P. ussuriensis var. ovoidea 8; 'Doyenné du Comice' $\times$ P. calleryana 12 and 'Doyenné $\mathrm{du}$ Comice' $\times P$. ussuriensis 18 belonged to the first

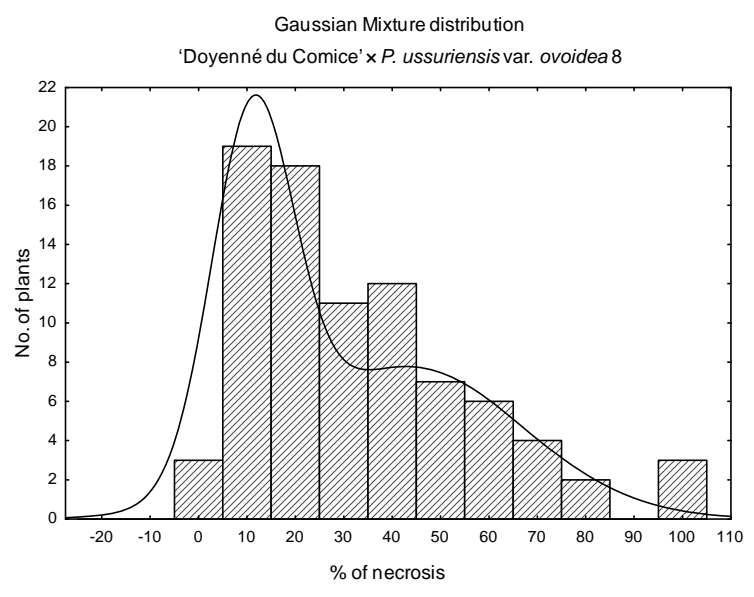

Figure 2. Gaussian mixture distribution of 'Doyenné du Comice' $\times P$. ussuriensis var. ovoidea 8 progeny. 


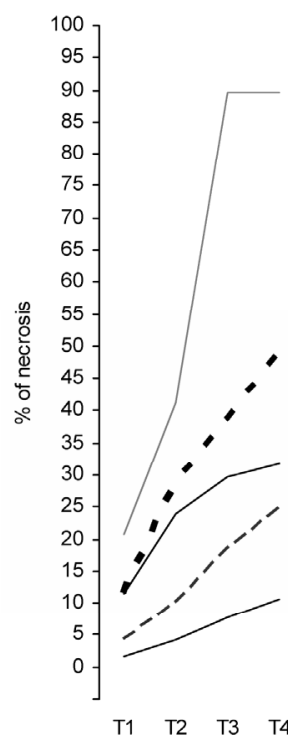

P. calleryana 12 - - 'Doyenné du Comice' - group 1

'Doyenné du Comice' $\mathrm{x}$

P. calleryana 12
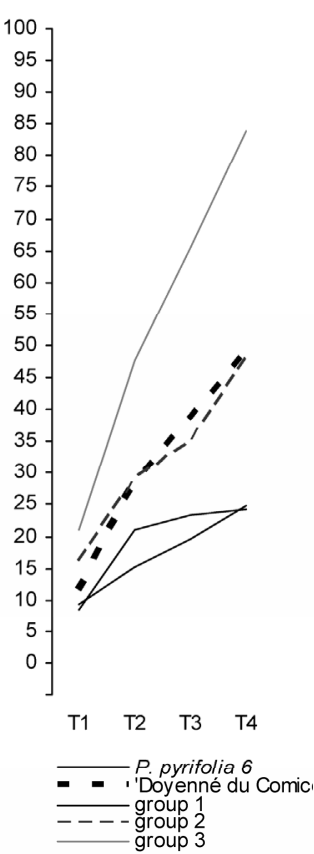

'Doyenné du Comice' $\mathrm{x}$

P. pyrifolia 6

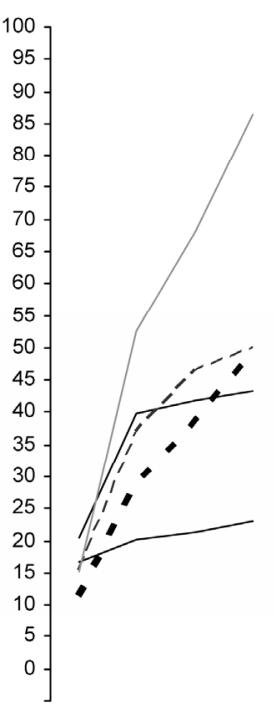

$\begin{array}{llll}\text { T1 } & \text { T2 } & \text { T3 } & \text { T4 }\end{array}$

P. pyrifolia19

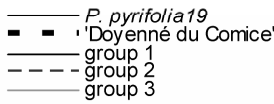$$
\text { 'Doyenné du Comice' }
$$

P. pyrifolia 19

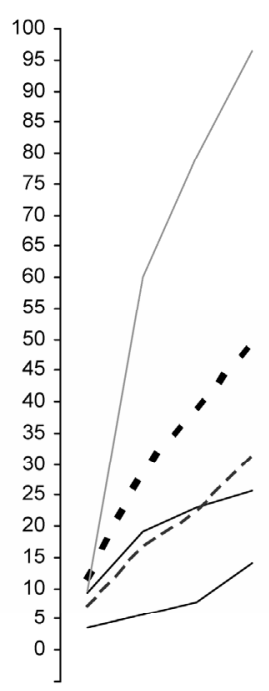

$\begin{array}{llll}\mathrm{T} 1 & \mathrm{~T} 2 & \mathrm{~T} 3 & \mathrm{~T} 4\end{array}$ - - 'Doyennè du Comice' - group 1

'Doyenné du Comice' P. ussuriensis 18

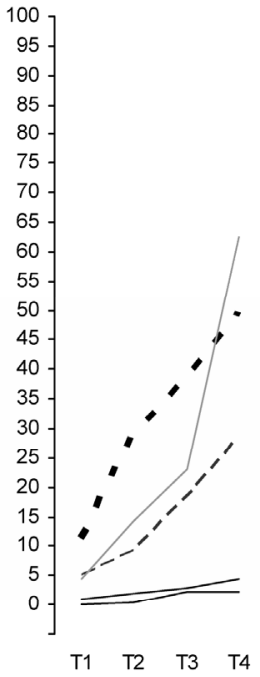

P. ussuriensis var.ovoidea 8

- 'Doyenné du Comice'

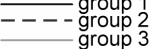

'Doyenné du Comice' $\mathrm{x}$

P. ussuriensis var. ovoidea

Figure 3. Major trend patterns of fire blight necrosis across 4 time measurements for groups of plants distinguished within interspecific crosses by cluster analysis, and parents. T1, T2, T3, T4 denote 4 time measurements after 1, 2, 3, and 4 weeks after inoculation, respectively.

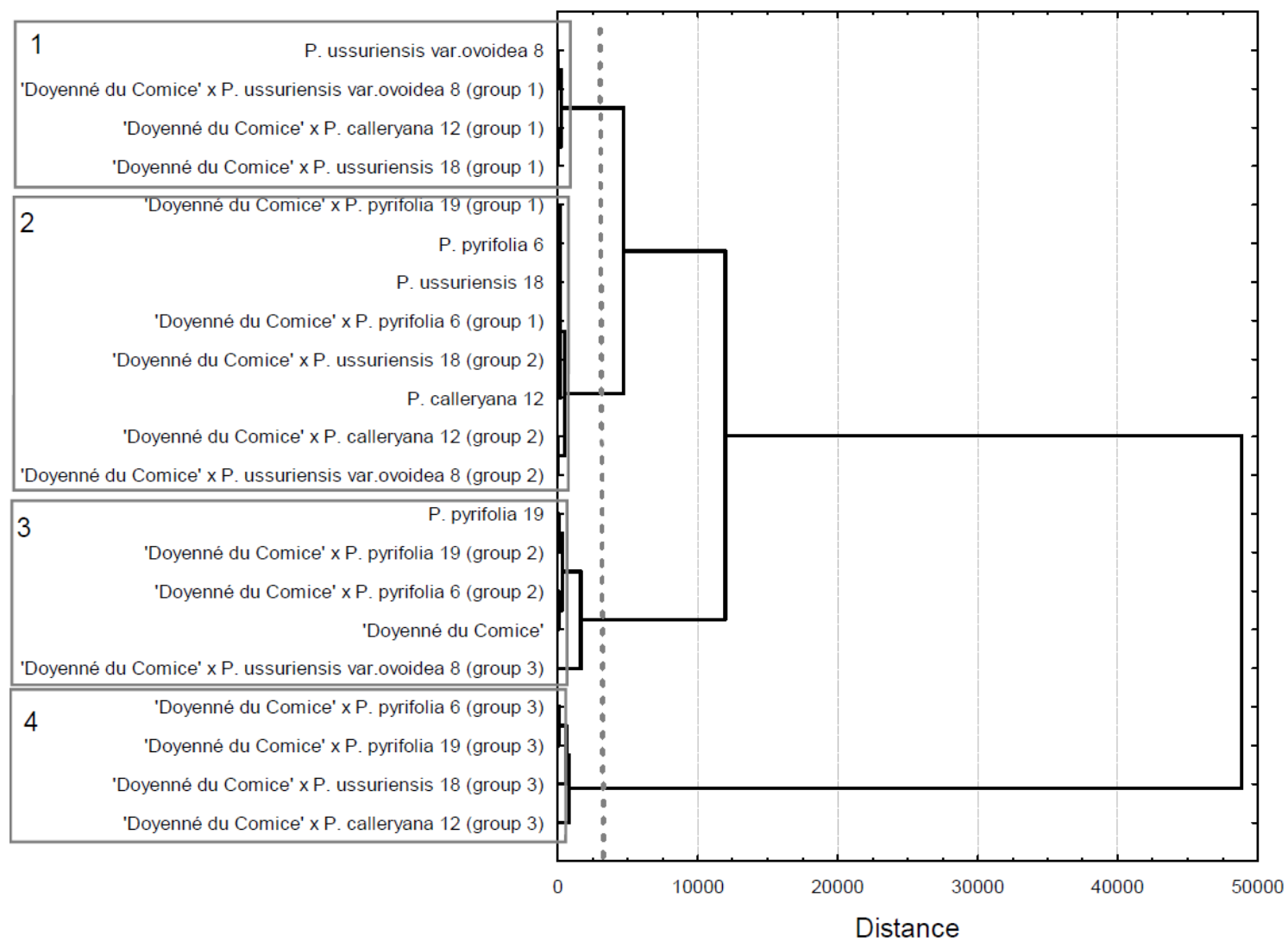

Figure 4. Dendrogram based on Ward's method of cluster analysis for the means of the fire blight necrosis for the groups of pear genotypes within crosses and parents across 4 time measurements. 
Table 4. Means of the fire blight necrosis (in \%) across 4 time measurements for groups of pear individuals originated from each cross (in the brackets percentage of plants within each cross), and parents. Respective averages for each distinguished homogenous cluster are provided.

\begin{tabular}{|c|c|c|c|c|c|c|}
\hline \multirow{2}{*}{ Genotypes and homogenous groups } & \multicolumn{4}{|c|}{ Times of measurement (weeks) } & \multirow{2}{*}{$\begin{array}{l}\text { No. of } \\
\text { clusters }\end{array}$} & \multirow{2}{*}{$\begin{array}{c}\text { Classification according } \\
\text { to Gardner }\end{array}$} \\
\hline & T1 & $\mathrm{T} 2$ & T3 & T4 & & \\
\hline P. ussuriensis var. ovoidea 8 & 0.0 & 0.5 & 2.3 & 2.3 & \multirow{5}{*}{1} & \multirow{5}{*}{$\begin{array}{l}\text { Highly resistant } \\
\text { and resistant }\end{array}$} \\
\hline 'Doyenné du Comice' $\times$ P. ussuriensis var. ovoidea 8 (group 1-41.4\%) & 0.9 & 2.0 & 3.0 & 4.6 & & \\
\hline 'Doyenné du Comice' $\times$ P. calleryana 12 (group $1-29.5 \%)$ & 1.7 & 4.3 & 7.7 & 10.5 & & \\
\hline 'Doyenné du Comice’ × P. ussuriensis 18 (group $1-40.0 \%$ ) & 3.8 & 5.7 & 7.7 & 14.2 & & \\
\hline Mean-cluster 1 & 1.6 & 3.1 & 5.2 & 7.9 & & \\
\hline 'Doyenné du Comice’ × P. pyrifolia 19 (group $1-16.7 \%$ ) & 16.7 & 20.3 & 21.2 & 23.0 & \multirow{9}{*}{2} & \multirow{8}{*}{$\begin{array}{l}\text { Resistant and moderately } \\
\text { susceptible }\end{array}$} \\
\hline P. pyrifolia 6 & 8.5 & 21.1 & 23.5 & 24.3 & & \\
\hline 'Doyenné du Comice' × P. calleryana 12 (group $2-68.2 \%)$ & 4.2 & 9.9 & 18.4 & 24.9 & & \\
\hline 'Doyenné du Comice’ × P. pyrifolia 6 (group $1-29.3 \%$ ) & 9.2 & 15.1 & 19.5 & 24.9 & & \\
\hline P. ussuriensis 18 & 9.3 & 19.2 & 23.0 & 25.7 & & \\
\hline 'Doyenné du Comice' $\times$ P. ussuriensis var. ovoidea 8 (group $2-40.4 \%$ ) & 5.1 & 9.1 & 18.2 & 28.4 & & \\
\hline ‘Doyenné du Comice’ × P. ussuriensis 18 (group 2-56.8\%) & 7.0 & 16.6 & 22.2 & 31.2 & & \\
\hline P. calleryana 12 & 11.5 & 24.0 & 29.7 & 31.8 & & \\
\hline Mean-cluster 2 & 8.9 & 16.9 & 22.0 & 26.8 & & \\
\hline P. pyrifolia 19 & 20.5 & 39.8 & 41.9 & 43.4 & \multirow{5}{*}{3} & \multirow{5}{*}{$\begin{array}{l}\text { Moderately susceptible } \\
\text { and susceptible }\end{array}$} \\
\hline 'Doyenné du Comice' $\times$ P. pyrifolia 6 (group 2-46.7\%) & 16.0 & 28.9 & 35.0 & 48.0 & & \\
\hline 'Doyenné du Comice' & 11.5 & 28.9 & 38.9 & 49.4 & & \\
\hline 'Doyenné du Comice' $\times$ P. pyrifolia 19 (group 2-33.3\%) & 15.6 & 36.9 & 46.5 & 50.0 & & \\
\hline 'Doyenné du Comice' $\times$ P. ussuriensis var. ovoidea 8 (group 3-18.2\%) & 4.6 & 14.1 & 22.9 & 62.6 & & \\
\hline Mean—cluster 3 & 13.6 & 29.7 & 37.1 & 50.7 & \multirow{6}{*}{4} & \multirow{6}{*}{$\begin{array}{l}\text { Susceptible and highly } \\
\text { susceptible }\end{array}$} \\
\hline 'Doyenné du Comice' $\times$ P. pyrifolia 6 (group 3-23.9\%) & 21.0 & 47.6 & 65.5 & 83.8 & & \\
\hline 'Doyenné du Comice' × P. pyrifolia 19 (group 3-50.0\%) & 15.4 & 52.6 & 68.1 & 86.5 & & \\
\hline 'Doyenné du Comice' $\times$ P. calleryana 12 (group 3-2.3\%) & 20.7 & 41.4 & 89.7 & 89.7 & & \\
\hline 'Doyenné du Comice' $\times$ P. ussuriensis 18 (group 3-3.2\%) & 9.6 & 60.0 & 79.3 & 96.3 & & \\
\hline Mean-cluster 4 & 16.7 & 50.4 & 75.6 & 89.1 & & \\
\hline
\end{tabular}

distinguished cluster (Figure 4). The highest share in the second cluster (moderately susceptible to fire blight) comprised individuals belonged to 'Doyenné du Comice' $\times$ P. calleryana 12 (group 2-68.2\%) and 'Doyenné du Comice' $\times$ P. ussuriensis 18 (group 2-56.8\%) hybrid families (Table 4, Figure 4). Clusters 3 and 4 contained only moderately susceptible to highly susceptible parents and homogenous groups, with the severity of necrosis higher than $40 \%$ at the last time of measurement. In the fourth cluster there were groups No. 3 of the following four hybrid families: 'Doyenné du Comice' $\times P$. pyrifolia 6, 'Doyenné du Comice' $\times$ P. pyrifolia 19, 'Doyenné du Comice' $\times$ P. calleryana 12 , and 'Doyenné du Comice' $\times$ P. ussuriensis 18 (Table 4, Figure 4).

It was revealed that the trend patterns of changes in percentage of necrosis in the subsequent measurements for parents and individuals grouped within hybrid families varied. A very quick increase of necrosis percentage from the first to the fourth time of measurement was observed for groups No. 3 of all crosses (Table 4, Figure 3). A similar pattern (quick increase of infection) was observed for 'Doyenné du Comice'. Asian pear species had different patterns of changes during the subsequent times of measurements. A quick increase to the second measurement and then only slight increase in the per cent of necrosis was observed except for $P$. ussuriensis var. ovoidea 8. In some cases patterns of infection for groups distinguished within hybrid families were quite different than patterns observed for parents, e.g. pattern for group 3 of 'Doyenné du Comice' $\times$ P. ussuriensis var. ovoidea 8 with a very quick increase of necrosis between the third and fourth measurement, and the pattern for group 1 of 'Doyenné du Comice' $\times$ P. pyrifolia 19 with a very slight increase of necrosis between the first and subsequent measurements (Table 4, Figure 3).

\section{DISCUSSION}

Genetic disease immunity or resistance is recognized as an important feature of the integrated pest management (IPM). Breeding disease-resistant fruit tree cultivars usually involves combining disease resistance with the best characters of susceptible cultivars. Horizontal resistance, which implies the possible development of at least some infection, might be useful as long as a crop loss is held to an acceptably low level - as in the case of fire blight. Genetic resistances are more often identified in wild species or botanical varieties. On several occasions, however, Pyrus species, believed to be resistant, did not always transmit this characteristic to their progenies $[23,25]$. Because of these uncertainties in the value of any given selection as a source of resistance, it is necessary to examine the available plant material for blight resistance before using it for breeding.

The purpose of the present investigations was to determine the possibility of using Asian pear species as 
donors of alleles determining fire blight resistance. Since all species of Pyrus are intercrossable and there are no major incompatibility barriers to interspecific hybridization in spite of the wide geographic distribution of the genus [26], we made wide crosses between European cultivar and Asian pear species.

The highest level of resistance was exhibited by a pear botanical variety $P$. ussuriensis var. ovoidea $8\left(1^{\text {st }}\right.$ class of resistance), although $P$. ussuriensis 18 itself was ranked to $2^{\text {nd }}$ class as resistant. According to Reimer [27] five Chinese cultivars derived from $P$. ussuriensis were immune under the Oregon conditions: 'Ba Li Hsiang', 'Chien Pa Li', 'Huang Hsiang Sui Li', 'Hung Guar Li', and 'Ta Tau Hang'. 'Star', 'Lee' and 'Mac' are fire blight resistant interspecific hybrids developed from $P$. ussuriensis $\times P$. serotina parentage [28]. Janick and Moore [29] pointed out that a high level of resistance occurs in greater frequency among the East Asian species, especially $P$. calleryana and $P$. ussuriensis. It is consistent with our investigations in the case of $P$. ussuriensis botanical variety, however P. calleryana 12 appeared to be moderately susceptible. Apart from P. ussuriensis 18 and $P$. ussuriensis var. ovoidea 8 we observed a variability in the degree of fire blight resistance between the different genotypes of the same species, i.e. between P. pyrifolia 6 and P. pyrifolia 19. Also Van der Zwet et al. [30] noted variation in the degree of resistance between species and between clones and selections within species. Others investigated the variability in fire blight resistance within $P$. betulaefolia, P. calleryana, P. pyrifolia, and in P. ussuriensis [23,27,31-34]. In $P$. pyrifolia, the degree of resistance ranged from very resistant to very susceptible [30]. In our studies P. pyrifolia 6 and P. pyrifolia 19 were ranked to resistant and moderately susceptible, respectively. 'Doyenné du Comice' was ranked to the $3^{\text {rd }}$ class (moderately susceptible) of resistance. It is opposite to results obtained by Le Lézec et al. [9]. In their studies 'Doyenné du Comice' appeared to be the most susceptible pear cultivar $\left(5^{\text {th }}\right.$ class, $80 \%-100 \%$ of necrosis). We suggest that this divergence of results could be determined by different parameters and conditions which were applied during resistance assessments procedures (different rootstocks for grafting, strains of the pathogen, different way of both inoculation and assessments of the disease progress, varied climatic conditions).

It was proven that in the interspecific crosses resistance has not to be consistently transmitted either by crossing a highly resistant with a very susceptible species or by crossing two highly resistant species $[23,25,30]$. The highest degree of overall resistance Van der Zwet et al. [30] obtained from crossing two moderately resistant parents.

Although P. calleryana 12, P. pyrifolia 19, P. pyrifolia 6 , and $P$. ussuriensis 18 in our studies were ranked to moderately susceptible and resistant classes (the last two) respectively, after crossing with moderately susceptible 'Doyenné du Comice' seedlings both more resistant and more susceptible than parental forms were observed, and apart from 'Doyenné du Comice' $\times P$. pyrifolia 19 cross combination, classified to resistant. It is an outcome of transgression phenomenon defined as the appearance of individuals in segregating populations that fall beyond their one or two parental phenotypes [35-37]. Transgressive segregation was observed both in the progeny derived from intraspecific and interspecific crosses [35, $36,38-43]$ although it was reported as being more probable in crosses between parents of different origin than between parents of related crosses [44]. Our observations are in agreement with noted transgressive segregation for a number of traits in many crop species [41-43,45-49]. Durel et al. [50] observed fire blight transgressive apple individuals more resistant or more susceptible than their respective parents in crosses between rootstock MM.106 and species 'Evereste' and between 'Golden Delicious' and the wild apple species Malus floribunda clone 821.

Rick and Smith [37] proposed three explanations for the occurrence of interspecific transgression: 1) de novo mutation induced by the wide cross itself; 2) complementary action of additive alleles i.e. two independent genes, neither of which would produce its effect in the absence of the other; and 3) unmasking of recessive genes normally held heterozygous in the wild species. De novo mutation due to the activation of quiescent transposable elements was demonstrated between the strains of Drosophila [51]. Evidence supporting both of the latter two hypotheses can be found in experiments involving a variety of plant species $[37,39,52]$. Other explanations for the occurrence of transgressive segregation are: 4) an elevated mutation rate in hybrids; 5) reduced developmental stability; 6) nonadditivity of allelic effects between loci or epistasis, phenomenon whereby the effects of a given gene on a biological trait are masked or enhanced by one or more other genes [53]; 7) nonadditivity of allelic effects within a locus or overdominance, where the phenotype of the heterozygote lays outside the phenotypical range of both homozygote parents; 8) chromosome number variation $[54,55]$.

Interspecific transgression has evolutionary implications as it can potentially affect the characters of adaptive significance leading to new races or species [56,57]. It is also significant with respect to crop improvement since it represents a potential source of novel genetic variation.

In our studies we observed generally continuous segregation distributions for fire blight resistance. Continuous distributions can be explained by the segregation of moderately large numbers of genes, or by monogenic inheritance with low heritability [23]. Discontinuous distribution of seedlings was noted in 'Doyenné du Comice' 
$\times$ P. pyrifolia 19 progeny. Resistant seedlings were not observed due to either a low number of seedlings or lack of valuable alleles in the male parent. However, for some traits with multifactorial inheritance, there is no gradation. Mendel studied these so-called "nonblending" traits, placing them in distinct categories [58].

Pear resistance to fire blight is generally considered as polygenic although monogenic resistance was observed. In a few cases with $P$. communis, $P$. ussuriensis and $P$. pyrifolia source of resistance, some seedling progenies had a segregation pattern that suggested a major gene inheritance, with the dominance of resistance [59]. Thompson et al. [25] found monogenic resistance only in $P$. ussuriensis.

The simplified assumption of polygenic inheritance is that all involved loci make an equal contribution to the symptoms of the disease with strictly additive effects [60-62]. This should result in a normal curve distribution of phenotypes. Quantitative traits are usually controlled by more than one gene with a small effect on the trait, and influenced by the environment, although traits controlled by a single gene with incomplete penetrance can be treated as quantitative traits for mapping and isolating the gene. In our studies polygenic inheritance of pear resistance to fire blight was observed in cross combinations of 'Doyenné du Comice' with the species: $P$. pyrifolia $19, P$. pyrifolia $6, P$. ussuriensis 18 , and $P$. calleryana 12. Right-side asymmetry of resistance distribution in 'Doyenné du Comice' $\times P$. calleryana 12 and 'Doyenné du Comice' $\times P$. ussuriensis 18 progenies indicate a major gene governed by resistance. Right-side asymmetry of resistance distribution, observed in 'Doyenné du Comice' $\times P$. ussuriensis 18 progeny, was confirmed in our previous studies by the presence of a major QTL in $P$. ussuriensis 18 LG9 which explains $61.9 \%$ of fire blight resistance variation [63]. Furthermore, despite the high susceptibility of 'Doyenné du Comice', 4 QTLs for fire blight resistance were found in this cultivar, which explain $25.6 \%$ of quantitative trait variation $[20,63]$. These data confirm the existence of interspecific transgression phenomenon, observed in the present study based on the infection level evaluation of seedlings belonging to 'Doyenné du Comice' $\times P$. ussuriensis 18 family. The presence of QTLs with small effect in 'Doyenné du Comice' testifies that the sources of fire blight resistance are present also in susceptible genotypes.

'Doyenné du Comice' $\times P$. ussuriensis var. ovoidea 8 is the sole interspecific cross where most of the seedlings were ranked in the $1^{\text {st }}$ class of resistance (Figure 1). The distribution of phenotypes is continuous. In spite of the fact that multifactorial traits all show a unimodal bellshaped distribution, not all traits that show a continuous distribution in the population are multifactorial traits [64]. Continuous variation in the expression of a trait can be due to both genetic (copy mumber variation, epistatic interactions, modifiers effects as penetrance and expressivity variation) and non-genetic factors (environmental). Considering the mechanism of resistance in the case of this particular hybrid family one could take into account the oligogenic, major gene or monogenic resistance. It has been extensively explored, especially in a backcross population, test cross or $\mathrm{F}_{2}$ progeny, the situation in which one locus determining resistance is associated to a bimodal distribution contributed by individuals heterozygous or homozygous at this locus. Since it was proven that despite the susceptibility of 'Doyenné du Comice', a putative QTL for fire blight resistance in its LG 4 is present [20], and the additive effect of resistant alleles derived from both parents in segregating population is occurring, the deliberation of 'Doyenné du Comice' $\times P$. ussuriensis var. ovoidea 8 in regard to this simplified, aforementioned situation of resistance inheritance should be avoided. This is also supported by the fact, that bellshaped like distribution which should be expected in the range of \% severity (necrosis) of susceptible female parent is skewed towards classes of less incidence of the disease (Figure 2).

In order to verify this proposition it would be worth comparing it to the opposite situations taking into account the fact, that predominant number of seedlings of the discussed hybrid family were attributed to the same $1^{\text {st }}$ class as a male parent. Considering strictly polygenic mode of inheritance it could be expected to observe a few seedlings in the parental resistance class. However, this situation did not occur. Respectively considering the situation, in which a few genes originated from one resistant parent determine the resistance, there would be expected more individuals than in polygenic mode of inheritance, but less than actually were observed.

These simplified considerations are based on assumptions of strictly semidominant alleles and strictly additive allele's effects. However, in living organisms there are complex genetic and epigenetic mechanisms for the molecular regulation of the phenotypic characteristics of a trait at multiple levels, including DNA sequence variation, pre- and post-transcription events, pre- and posttranslation processing, and the hierarchical or global gene network [65].

Continuous distribution is attributed not just to quantitative, either to one gene controlled traits with either incomplete penetrance (caused by the transcriptional and translational regulators known as epigenetic factors, while the expression level of the gene of interest is the same in all offsprings) or variable expressivity (e.g. caused by the mutations in two different positions of the same gene), that can be treated as quantitative traits for mapping and isolating the gene [66]. Skewness of the distribution in 'Doyenné du Comice' $\times P$. ussuriensis var. ovoidea 8 
with $58 \%$ of its offspring ranked to two resistant classes, and a contribution of resistant alleles from female parent suggests the possibility of monogenic inheritance with 50 per cent heritability and dominance of resistance. This is a first report on putative monogenic resistance in ussurian pear botanical variety. Similar pattern of distributions with monogenic source of resistance were observed by Layne et al. [23] and described by Allard [24]. However, our suggestion on the possible monogenic resistance with the dominance in P. ussuriensis var. ovoidea 8 should be verified molecularly. It is also possible by e.g. studying further progenies of 'Doyenné du Comice' $\times P$. ussuriensis var. ovoidea 8 interspecific cross.

Our studies suggest that, while wild species or cultivars may not display a character of interest (or have reduced amounts of that character), it is likely that they possess alleles that can improve the character. By combining wild species crosses with molecular linkage maps, it is possible to identify and selectively introgress new alleles that can improve characters for which genotypes are normally not considered to be a source of useful variation.

In our studies the best sources of resistance appeared to be $P$. ussuriensis 18 and $P$. ussuriensis var. ovoidea 8 , which crossed with 'Doyenné du Comice' transmitted the resistance to $65 \%$ and $58 \%$ of its offspring ranked to resistant classes, respectively. The potential use of these genotypes as donors of resistant alleles is especially possible since new breeding techniques are available such as Zinc Finger Nuclease (ZFN) technology, Oligonucleotide Directed Mutagenesis (ODM), cisgenesis and intragenesis, or RNA-dependent DNA methylation (RdDM).

\section{ACKNOWLEDGEMENTS}

This research was supported by the Polish Ministry of Science and Higher Education (grant No. 2PO6R01929).

\section{REFERENCES}

[1] Denning, W. (1794) On the decay of apple trees. Transactions of the Society for the Promotion of Agriculture, Arts and Manufacturers, 1, 219-222.

[2] Burrill, T.J. (1871) Report on vegetable physiology. Transactions of the Illinois State Horticultural Society, 5, 197199.

[3] Arthur, J.C. (1885) Proof that the disease of trees known as Pear-Blight is directly due to bacteria. NY (Geneva) State Experimental Station Bulletin, 2, 1-4.

[4] Hartman, H. (1957) Catalog and evaluation of the pear collection at Oregon Agriculture Experiment Station. Oregon Agricultural Experimental Station Technical Bulletin, 41.

[5] Bell, A.C., Ranney, T.G., Eaker, T.A. and Sutton, T.B. (2005) Resistance to fire blight among flowering pears and quince. HortScience, 40, 413-415.

[6] Oitto, W.A., Van der Zwet, T. and Brooks, H.J. (1970) Rating of pear cultivars for resistance to fire blight. HortScience, 5, 474-476.

[7] Van der Zwet, T. and Oitto, W.A. (1972) Further evaluation of the reaction of "resistant" pear cultivars to fire blight. HortScience, 7, 395-397.

[8] Thibault, B., Lecomte, P., Hermann, L. and Belouin, A. (1987) Assessment of the susceptibility to Erwinia amylovora of 90 varieties or selections of pear. Acta Horticulturae, 217, 305-309.

[9] Le Lézec, M., Lecomte, P., Laurens, F. and Michelesi, J.C. (1997) Sensibilité variétale au feu bactérien [3 parts]. Arboriculture Fruitière, 503, 57-61; 504, 33-37; 505, 31 40.

[10] Vanneste, J.L. (2000) Fire blight. The disease and its causative agent. Erwinia amylovora. CABI Publishing, New York. doi:10.1079/9780851992945.0000

[11] Postman, J.D. (2008) The USDA quince and pear genebank in Oregon, a world source of fire blight resistance. Acta Horticulturae, 793, 357-362.

[12] Hedrick, U.P. (1921) The pears of New York. TwentyNinth Annual Report of State of New York, Part II, Department of Agriculture, 2, JB Lyon Co., Albany.

[13] Patten, C.G. (1917) Origin and development of hardy, blight-resistant pears. The Minnesota Horticulturist, 45, 97-102.

[14] Janick, J. and Moore, J.N. (1996) Fruit breeding. Tree and tropical fruits. John Wiley \& Sons, New York.

[15] Van der Zwet, T. and Keil, H.L. (1979) Fire blight: A bacterial disease of rosaceous plants. Handbook, 510, United States Department of Agriculture.

[16] Yamamoto, T., Kimura, T., Shoda, M., Imai, T., Saito, T., Sawamura, Y., Kotobuki K., Hayashi T. and Matsuta, N. (2002) Genetic linkage maps constructed by using an interspecific cross between Japanese and European pears. Theoretical Applied Genetics, 106, 1-18.

[17] Yamamoto, T., Kimura, T., Saito, T., Kotobuki, K., Matsuta, N., Liebhard, R., Gessler, C., van de Weg, W.E. and Hayashi, T. (2004) Genetic linkage maps of Japanese and European pears aligned to the apple consensus map. Acta Horticulturae, 663, 51-56.

[18] Pierantoni, L., Cho, K.-H., Shin, I.-S., Chiodini, R., Tartarini, S., Dondini, L., Kang, S.J. and Sansavini, S. (2004) Characterization and transferability of apple SSRs to two European pear F1 populations. Theoretical Applied Genetics, 109, 1519-1524. doi:10.1007/s00122-004-1775-9

[19] Dondini, L., Pierantoni, L., Gaiotti, F., Chiodini, R., Tartarini, S., Bazzi, C. and Sansavini, S. (2004) Identifying QTLs for fire-blight resistance via a European pear (Pyrus communis L.) genetic linkage map. Molecular Breeding, 14, 407-418. doi:10.1007/s11032-004-0505-y

[20] Bokszczanin, K., Dondini, L. and Przybyla, A.A. (2009) First report on the presence of fire blight resistance in linkage group 11 of Pyrus ussuriensis maxim. Journal of Applied Genetics, 99-104. doi:10.1007/BF03195660

[21] Bell, A.C., Ranney, T.G. and Eaker, T.A. (2004) Resis- 
tance to fire blight among flowering pears and quince. HortScience, 40, 413-415.

[22] Gardner, R.G., Cummins, J.N. and Aldwinckle H.S. (1980) Inheritance of fire blight resistance in Malus in relation to rootstock breeding. Journal of the American Society for Horticultural Science, 105, 912-916.

[23] Layne, R.E.C., Bailey, C.H. and Hough, L.F. (1968) Efficacy of transmission of fire blight resistance in Pyrus. Canadian Journal of Plant Science, 48, 231-243. doi:10.4141/cjps68-044

[24] Allard, R.W. (1960) Principles of plant breeding. John Wiley and Sons, New York.

[25] Janick, J. and Moore, J.N. (1975) Advances in fruit breeding. Purdue University Press, West Lafayette.

[26] Thompson, S.S., Janick, J. and Williams, E.B. (1962) Evaluation of resistance to fire blight of pear. Proceedings of American Society of Horticultural Sciences, 80, 105-113.

[27] Westwood, M.N. and Bjornstad, H.O. (1971) Some fruit characteristics of interspecific hybrids and extent of selffertility in Pyrus. Bulletin of the Torrey Botanical Club, 98, 22-24. doi:10.2307/2483493

[28] Reimer, F.C. (1925) Blight resistance in pears and characteristics of pear species and stocks. Oregon Agricultural Experimental Station Bulletin, 214, 99.

[29] Lespinasse, Y. and Aldwinckle, H.S. (2000) Breeding for resistance to fire blight. In: Vanneste, J.L., Ed., Fire Blight: The Disease and Its Causative Agent, Erwinia amylovora, CABI Publishing, Wallingford, 253-273. doi:10.1079/9780851992945.0253

[30] Van der Zwet, T., Oitto, W.A. and Westwood, M.N. (1974) Variability in degree of fire blight resistance within and between Pyrus species, interspecific hybrids, and seedling progenies. Euphytica, 23, 295-304. doi:10.1007/BF00035871

[31] Anderson, H.W. (1928) Seek pear resistant to destructive fire blight. Agricultural Experimental Station and Annual Report III, 41, 263-264.

[32] Cameron, H.R., Westwood, M.N. and Lombard, P.B. (1968) Resistance of Pyrus species and cultivars to Erwinia amylovora. Phytopathology, 59, 1813-1815.

[33] Lamb, R.C. (1960) Resistance to fire blight of pear varieties. Proceedings of the American Society for Horticultural Science, 75, 85-88.

[34] Mowry, J.B. (1964) Maximum orchard susceptibility of pear and apple varieties to fireblight. Plant Disease Report, 48, 272-276.

[35] Lotsy, J.P. (1916) Evolution by means of hybridization. M. Nijhoff, The Hague.

[36] Darlington, C.D. and Mather, K. (1949) The elements of genetics. Allen \& Unwin, London.

[37] Rick, C.M. and Smith, P.G. (1953) Novel variation in tomato species hybrids. The American Naturalist, 88, 359373. doi:10.1086/281796

[38] Brainerd, E. (1924) Some natural violet hybrids of North American Vermont Agricultural Experimental Station Bulletin, No. 239.
[39] Vega, U. and Frey, K.J. (1980) Transgressive segregation in inter and intraspecific crosses of barley. Euphytica, 29, 585-594. doi:10.1007/BF00023206

[40] Quarrie, S.A. and Mahmood, A. (1993) Improving salt tolerance in hexaploid wheat. Annual Report AFRC Institute of Plant Science Research, 4, 2.

[41] Luzzi, B.M., Boerma, H.R. and Hussey, R.S. (1994) Inheritance of resistance to the southern root-knot nematode in soybean. Crop Science, 34, 1240-1243. doi:10.2135/cropsci1994.0011183X003400050018x

[42] Hou, L.M., Ullrich, S.E. and Kleinhofs, A. (1994) Inheritance of anther culture traits in barley. Crop Science, 34, $1243-1247$. doi:10.2135/cropsci1994.0011183X003400050019x

[43] Singh, S.P., Khanna, K.R., Shukla, S., Dixit, B.S. and Banerji, R. (1995) Prospects of breeding opium (Papaver somniferum L.) as a highlinoleic-acid crop. Plant Breeding, 114, 89-91. doi:10.1111/j.1439-0523.1995.tb00768.x

[44] Bordelon, B.P. (1981) Transgressive segregation for resistance in barley to net blotch. M.S. Thesis, Montana State University, Bozeman, 86.

[45] Cherif, M. and Harrabi, M. (1993) Transgressive segregation for resistance to Pyrenophora teres in barley. Plant Pathology, 42, 617-621. doi:10.1111/j.1365-3059.1993.tb01542.x

[46] Brooks, S.J., Moore, J.N. and Murphy, J.B. (1993) Quantitative and qualitative changes in sugar content of peach genotypes Prunus persica (L.) Batsch. Journal of the American Society for Horticultural Science, 118, 97-100.

[47] Oard, J.H. and Hu, J. (1995) Inheritance and characterization of pollen fertility in photoperiodically sensitive rice mutants. Euphytica, 82, 17-23. doi:10.1007/BF00028705

[48] Zhang, G., Sebolt, A.M., Sooriyapathirana, S.S., Wang, D., Bink, M., Olmstead, J.W. and Iezzoni, A.F. (2010) Fruit size QTL analysis of an F1 population derived from a cross between a domesticated sweet cherry cultivar and a wild forest sweet cherry. Tree Genetics and Genomes, 6 , 25-36. doi:10.1007/s11295-009-0225-X

[49] Hampson, C.R. and Sholberg, P.L. (2008) Estimating combining ability for fire blight resistance in apple progenies. Acta Horticulturae, 793, 337-343.

[50] Durel, C.-E., Denancé, C. and Brisset, M.-N. (2009) Two distinct major QTL for resistance to fire blight co-localize on linkage group 12 in apple genotypes "Evereste" and Malus floribunda clone 821. Genome, 52, 139-147.

[51] Engels, W.R. (1983) The P family of transposable elements in Drosophila. Annual Review Genetics, 17, 315-344. doi:10.1146/annurev.ge.17.120183.001531

[52] Frey, K., Cox, T.S., Rodgers, D.M. and Ramel-Cox, P. (1981) Increasing cereal yields with genes from wild and weedy species. Proceedings of the 15th International Genetics Congress, New Delhi, 12-21 December, 51-68.

[53] Moore, J.H. (2005) A global view of epistasis. Nature Genetics, 37, 13-14. doi:10.1038/ng0105-13

[54] Grant, V. (1975) Genetics of flowering plants. Columbia University Press, New York. 
[55] Voigt, P.W. and Tischler, C.R. (1994) Leaf characteristic variation in hybrid lovegrass populations. Crop Science, 34, 679-684. doi:10.2135/cropsci1994.0011183X003400030015x

[56] Stebbins, G.L. Jr. (1950) Variation and evolution in plants. Columbia University Press, New York.

[57] Lewontin, R.C. and Birch, L.C. (1966) Hybridization as a source of variation for adaptation to new environments. Evolution, 20, 315-336. doi:10.2307/2406633

[58] Olby, R.C. (2000) Horticulture: The font for the baptism of genetics. Nature Reviews Genetics, 1, 65-70. doi:10.1038/35049583

[59] Bell, R.L., Quamme, H.A., Layne, R.E.C. and Skirvin, R.M. (1996) Pears. In: Janick J. and Moore J.N., Eds., Fruit Breeding: Tree and Tropical Fruits, Wiley and Sons, New York, 441-514.

[60] Lange, K. (1997) An approximate model of polygenic inheritance. Genetics, 147, 1423-1430.

[61] Corva, P.M. and Medrano, J.F. (2001) Quantitative trait loci (QTLs) mapping for growth traits in the mouse: A review. Genetics Selection Evolution, 33, 105-132. doi:10.1186/1297-9686-33-2-105

[62] Acquaah, G. (2007) Principles of plant genetics and breeding. Wiley-Blackwell, Hoboken.

[63] Bokszczanin, K. (2009) Identyfikacja loci cech ilościowych warunkujących odporność gruszy na zarazę ogniową (Erwinia amylovora). (Identification of quantitative trait loci for fire blight (Erwinia amylovora) resistance in pear). Ph.D. Thesis, Warsaw University of Life Science, Warsaw.

[64] Van der Plank, J.E. (1982) Host-pathogen interactions in plant disease. Academic Press, New York.

[65] Zhu, M., Yu, M. and Zhao, S. (2009) Understanding quantitative genetics in the systems biology era. International Journal of Biological Sciences, 5, 161-170. doi:10.7150/ijbs.5.161

[66] Liu, B.-H. (1998) Statistical genomics: Linkage, mapping, and QTL analysis. CRC Press, Boca Raton. 